\title{
Reflective Teaching-Learning Process of Integrating Metaphorical Thinking and Visual Imagery
}

\author{
Cittoor Girija Navaneedhan \\ F4, Second Main Road, Annanagar East, Chennai, India \\ Email: girija60@rediffmail.com
}

Received October 27, 2011; revised November 29, 2011; accepted January 25, 2012

\begin{abstract}
Reflective teaching-learning methodology is a self evaluation technique adopted by teachers to promote motivation within one's own self in order to make teaching-learning process more interesting and effective task. If the teacher integrates mind tools such as metaphorical thinking and visual imagery in his/her reflective teaching methodology, the teaching-learning process becomes more challenging. The teacher will develop radiant or divergent thinking as the result teaching-learning process becomes learner centered. The work shop targets teachers or teacher trainees to get acquainted with the technique of practicing metaphorical thinking and visual imagery in reflective teaching methodology. Metaphorical thinking [1] is a natural phenomenon of the human brain to find similarity between two different universes of meaning. Visual imagery is another natural phenomenon in which human brain associates text material with structures in one's own mind's eye. Integrating these two mind tools consciously in reflective teaching-learning process transforms the teachers as well as teacher trainees to highly self motivated individuals.
\end{abstract}

Keywords: Metaphorical Thinking; Visual Imagery

\section{Introduction}

Reflective teaching methodology is a self inquiry approach which is constructivist in nature meaning that the learners construct new knowledge from their experiences related to the mental frame work that already exists in their mind (Jean Piaget 1967). The role of the teacher is to foster constructivist approach in teaching-learning process integrating metaphorical thinking and visual imagery takes. This could be achieved by emphasizing active and cooperative learning seeking the connection between theory and practice of abstract concepts in the respective subject matter. Reflective teaching methodology enables the teacher to involve, recognize, examine, ruminate over the way an individual teaches. Hence forth, it could be very well said that the teachers possess their own background and experience, bring certain beliefs, assumptions, knowledge, attitudes and values to teaching. The practice of Reflective teaching explores the implications of all these complex factors with the intention of understanding and improving teaching-learning practice. D. Schon [2] suggested that reflective teaching practice is a continuous process and involves learner thoughtfully considering one's own experience in applying knowledge to practice while being taught by professionals. It helps the individual's to develop their own personality. Teresa B. Carlson [3] conducted a study on thirty-three pre-service teachers from a Physical Education Teacher
Education (PETE) class at the University of Queensland. At the beginning of the course, they were asked to design metaphors about their own teaching describing what kind of teacher they wanted to become. The aim of the assignment although was to encourage the pre-service teachers to articulate their underlying beliefs about teaching and learning and the effectiveness of using metaphors in their own design of teaching-learning process was evaluated by conducting interviews after a period of eighteen months. The findings of the study revealed that though the pre-service teachers used different metaphors for the same content according to their individual teaching-learning design it was found to contribute to their teaching growth.

\section{Self Inquiry Reflective Teaching Model}

The main objective of self inquiry reflective teaching model is to frame learning objectives of a selected topic based on Benjamin Bloom's Learning Taxonomy (1956) namely 1) knowledge; 2) understanding; 3) application; 4) analysis; 5) synthesis and 6) evaluation or creating. The learning objectives once framed based on these domains the teacher has to practice the self inquiry reflective model as shown in Figure 1.

Metaphorical thinking is a direct comparison between two unrelated or indirectly linked things is called a 


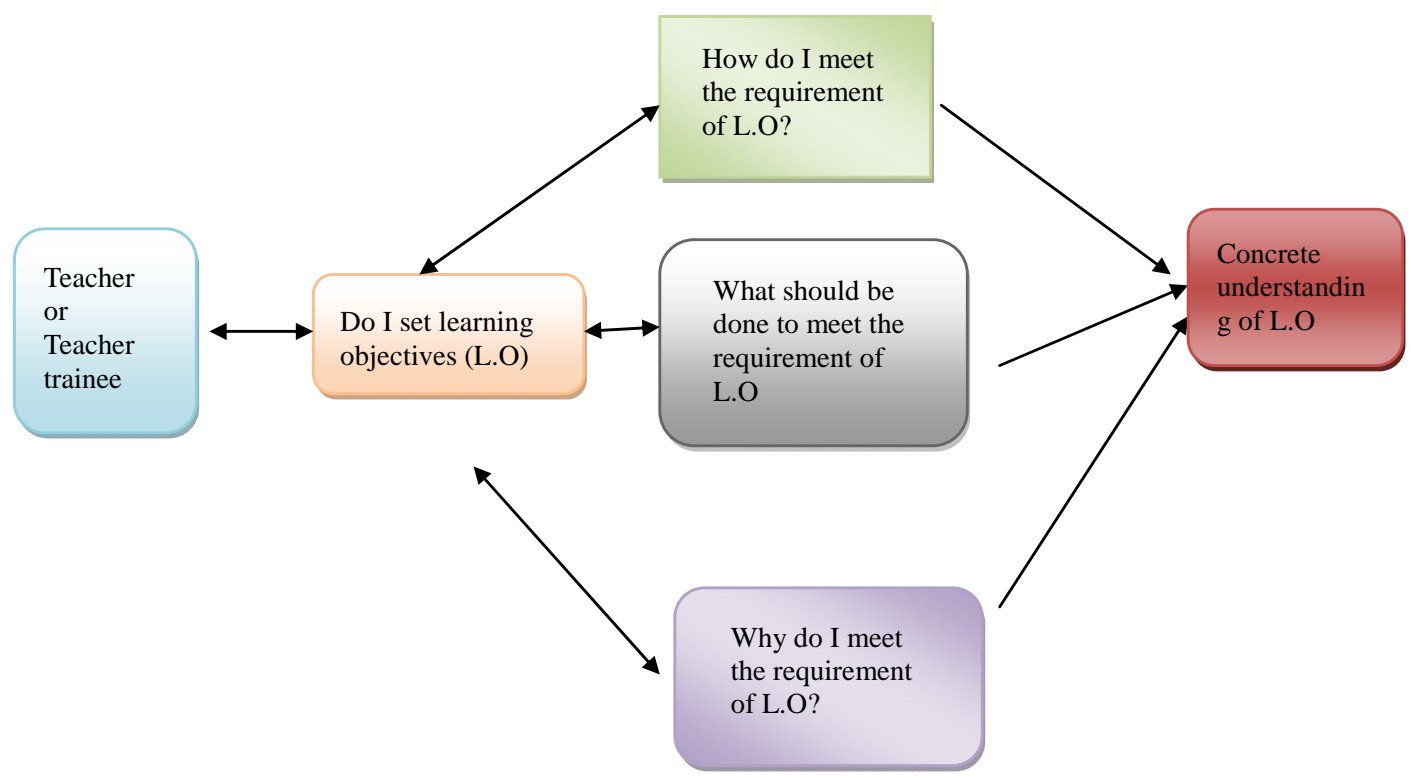

Figure 1. Integration of reflective teaching methodology with metaphorical thinking.

metaphor and metaphors can create strong images that can be used to great effect in everyday communications and thinking. The teacher or teacher trainee should practice integration of reflective teaching methodology with metaphorical thinking in their day to day teaching learning process, a model exercise given below shows how the teacher or the teacher trainee should practice considering a subject topic introduction to "Electro Chemistry".
The teacher should frame basic five learning objectives (Bloom, Benjamin S. [4]) relevant to the topic;

- To recall the uses of electricity in everyday life;

- To understand the term Electro Chemistry;

- To differentiate Electrochemical cell and Electrolytic cell;

- To analyze the principle of Electrochemical cell;

- To apply the principle of Electrochemical cell.

\begin{tabular}{|c|c|}
\hline Learning objectives & $\begin{array}{l}\text { Suitable metaphorical thinking skills to be developed by the teacher or teacher trainee along with } \\
\text { reflective teaching practice. }\end{array}$ \\
\hline $\begin{array}{l}\text { To recall the uses of } \\
\text { electricity in everyday life }\end{array}$ & $\begin{array}{l}\text { Teacher or teacher trainee should ask question like what is the similarity between pressing an electric switch } \\
\text { and giving chocolates to a child. This type of questioning triggers the mind of students to think about the } \\
\text { similarity between the two stimulants which are totally different but one thing is common that is in the first } \\
\text { instant the room glows and in the second instant the child's face glows. Therefore, the students would } \\
\text { understand that both the stimulants brings certain changes in the process and tries to learn more about it. }\end{array}$ \\
\hline $\begin{array}{l}\text { To differentiate Electrochemical } \\
\text { cell and Electrolytic cell }\end{array}$ & $\begin{array}{l}\text { The teacher should initiate metaphorical thinking by highlighting the similarity between Electrochemical and } \\
\text { Electrolytic cell with that of Anabolism and Catabolism taking place in living cell in terms of energy. }\end{array}$ \\
\hline $\begin{array}{l}\text { To analyze the principle of } \\
\text { Electrochemical cell }\end{array}$ & $\begin{array}{l}\text { The teacher should explain the principle in construction of Electrochemical step by step using scientific } \\
\text { conventions similar to construction of a building. }\end{array}$ \\
\hline $\begin{array}{l}\text { To apply the principle of } \\
\text { Electrochemical cell }\end{array}$ & $\begin{array}{l}\text { The teacher should give exercise based on the principle of Electrochemical cell and ask to solve the problems } \\
\text { and relate them to electrical appliances used in everyday life. }\end{array}$ \\
\hline
\end{tabular}

\section{Integration of Reflective Teaching Methodology with Visual Imagery}

Visual imagery is a mental tool (Marks, D. F. 1999, [5]) which when practiced helps the individuals to perceive information by developing an image of the information. For example the learning of English Alphabets with suitable pictures of animals, plants, fruits or vegetables so that the child perceives the information of the alphabets by connecting with the mental image of the relevant picture. The integration of reflective teaching methodology with visual imagery relevant to learning objectives in the topic introduction to "Electro Chemistry" is shown below. 


\begin{tabular}{|c|c|}
\hline Learning objectives & $\begin{array}{l}\text { Suitable metaphorical thinking skills to be developed by the teacher or teacher trainee along with } \\
\text { reflective teaching practice. }\end{array}$ \\
\hline $\begin{array}{l}\text { To recall the uses of electricity } \\
\text { in everyday life }\end{array}$ & $\begin{array}{l}\text { The teacher should initiate the perception of students regarding the uses of electricity by visualizing the } \\
\text { electrical and electronic appliances present in their respective homes and ask to themselves how these } \\
\text { appliances work. }\end{array}$ \\
\hline $\begin{array}{l}\text { To understand the term } \\
\text { Electro Chemistry }\end{array}$ & Here the teacher should initiate the visualization of lightening and its effect when it struck objects. \\
\hline $\begin{array}{l}\text { To differentiate Electrochemical } \\
\text { cell and Electrolytic cell }\end{array}$ & $\begin{array}{l}\text { The teacher should initiate visualization of rusting of iron grill or any iron object which they come across } \\
\text { in everyday life and how it improves its appearance on painting. }\end{array}$ \\
\hline $\begin{array}{l}\text { To analyze the principle of } \\
\text { Electrochemical cell }\end{array}$ & $\begin{array}{l}\text { The teacher should initiate the visualization of the construction of Electrochemical by showing a } \\
\text { diagram using scientific conventions and practice to view it their mind's eye. }\end{array}$ \\
\hline $\begin{array}{l}\text { To apply the principle of } \\
\text { Electrochemical cell }\end{array}$ & $\begin{array}{l}\text { The teacher should initialize the visualization of their own understanding of the concepts by solving the } \\
\text { problems and imagine the working of cell , the flow of electrons from anode to cathode etc. }\end{array}$ \\
\hline
\end{tabular}

\section{Conclusions}

By integrating visual imagery and metaphorical thinking in reflective teaching methodology enables the teacher to possess a clear objective of what to be taught and how to proceed through the process of teaching and learning (for example, the learning of English Alphabets with suitable pictures of animals, plants, fruits or vegetables, can make child perceive information of alphabets by connecting with the mental image of the relevant picture). The reflective teaching methodology integrated with visual imagery and metaphorical thinking kindles the thought process of the learner and helps to retain the information prioritizing and rearranging ideas to create meaningful concept as well as to organize information from their class notes or textbook chapters. Thus, it provides students with a number of ways to recode information, and this recoding facilitates long-term memory storage and retrieval. Visual imagery is important in facilitating longterm retention. Self-discovered imagery produces better retention than given imagery or verbal definition. The visual imagery technique activates visual mental images induced by stored information and the input from the eyes induces a pattern of activation during perception as Images are cognitive reflections and notations of a real world. Similarly practice of metaphorical thinking helps learners to solve problems easily as it promotes brain stimulation naturally by enhancing the synthesis of neuro transmitters. It also helps learners to undergo insightful transformations through advanced thinking developed through pithy, thought-provoking statements. Hence, these reflective metaphors (Treffinger, D. and Isaksen, S. Teaching [6]) lead students to higher plateaus and solidify deeper understandings. Students demonstrate a deeper understanding of the learning process through the creation of metaphorical connections. These kinds of creations encourage dialogue among classmates and cause revisions and justifications to occur. Teachers by implementing the technique (in Bloom's taxonomy 1956 suggests metaphorical thinking as the highest level of thinking) should set the learning bar higher by expecting higher-level thinking to flourish in the classroom. By integrating metaphorical thinking and visual imagery, the reflective teaching methodology enables the teacher to possess a clear idea of what to be taught and how to proceed through the process of teaching and learning. Therefore, it is concluded that integration of metaphorical thinking and visual imagery in reflective teaching methodology is known to promote the following mental skills in students namely

- Valuing: choosing to employ a pattern of intellectual behaviors rather than other, less productive patterns;

- Having the inclination: feeling the tendency toward employing a pattern of intellectual behaviors;

- Being alert: perceiving opportunities for, and appropriateness of employing the pattern of behavior;

- Being capable: possessing the basic thinking skills and capacities to carry through with the behaviors;

- Making a commitment: reflecting on and constantly striving to improve performance of the pattern of intellectual behavior.

The development of above mental skills enables them acquire the qualities such as:

1) Persisting when the solution to a problem is not readily apparent;

2) Managing impulsivity;

3) Listening to others with understanding and empathy;

4) Thinking flexibly;

5) Thinking about our own thinking: metacognition;

6) Striving for accuracy and precision;

7) Asking questioning and posing problems;

8) Applying past knowledge to new situations;

9) Thinking and communicating with clarity and precision;

10) Gathering data through all senses;

11) Creating, imagining and innovating;

12) Thinking interdependently;

13) Learning to behave intelligently.

Therefore, the goal of teaching-learning should be to liberate and develop more fully these habits of mind and the skills associated with them. 


\section{REFERENCES}

[1] A. Costa, "Developing Minds: A Resource Book for Teaching Thinking," VA: Association for Supervision and Curriculum Development, Alexandria, 1985.

[2] D. Schon, "The Reflective Practitioner: How Professionals Think in Action,” Basic Books, New York, 1993.

[3] T. B. Carlson, "Using Metaphors to Enhance Reflectiveness among Preservice Teachers," The Journal of Physical Education, Recreation \& Dance, Vol. 7, 2001.

[4] S. Benjamin, "Taxonomy of Educational Objectives,"
Allyn and Bacon, Boston, 1956.

[5] D. F. Marks, "Consciousness, Mental Imagery and Action,” British Journal of Psychology, Vol. 90, No. 4, 1999, pp. 567-585. doi:10.1348/000712699161639

[6] D. Treffinger and S. Isaksen, "Teaching for Creative Learning and Problem Solving,” In: A. Costa, Ed., Developing Minds: A Resource Book for Teaching Thinking. VA: Association for Supervision and Curriculum Development, Alexandria, 1986. 